\title{
Protection and rights related to pregnancy and maternity in EU law
}

\section{Susanne Burri}

\section{Q OpenEdition \\ 1 Journals}

\section{Electronic version}

URL: https://journals.openedition.org/rdctss/1305

DOI: $10.4000 /$ rdctss.1305

ISSN: 2262-9815

This article is a translation of:

Protection et droits liés à la grossesse et à la maternité en droit de l'UE - URL : https://

journals.openedition.org/rdctss/1654 [fr]

Publisher

Centre de droit comparé du travail et de la sécurité sociale

Printed version

Date of publication: 1 December 2019

Number of pages: 16-25

ISSN: $2117-4350$

\section{Electronic reference}

Susanne Burri, "Protection and rights related to pregnancy and maternity in EU law", Revue de droit comparé du travail et de la sécurité sociale [Online], 4 | 2019, Online since 01 novembre 2021, connection on 28 juin 2022. URL: http://journals.openedition.org/rdctss/1305 ; DOI: https://doi.org/10.4000/ rdctss. 1305

\section{(c) $(1) \Theta(\Theta$}

La Revue de droit comparé du travail et de la sécurité sociale est mise à disposition selon les termes de la Licence Creative Commons Attribution - Pas d'Utilisation Commerciale - Pas de Modification 4.0 International. 


\title{
PROTECTION AND RIGHTS RELATED TO PREGNANCY AND MATERNITY IN EU LAW
}

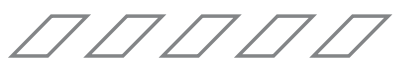

\section{RÉSUMÉ}

La Cour de Justice a dès 1990 fermement établi le principe de non-discrimination fondée sur le sexe en relation aux femmes enceintes dans l'accès à l'emploi, les conditions de travail et le licenciement. Des obligations spécifiques reposent sur les États membres et les employeurs depuis l'adoption de la directive 92/85, qui n'a pas été amendée depuis. La jurisprudence de la Cour a considérablement renforcé la protection contre un refus d'embauche ou un licenciement liés à la grossesse. Cet article propose un court aperçu de la législation de l'UE dans ce domaine et une analyse de la jurisprudence de la Cour sur la protection et les droits liée à la grossesse et la maternité.

MOTS CLÉS : Discriminations fondées sur le sexe, grossesse, maternité, droit de l'UE, jurisprudence de la CJUE.

\begin{abstract}
The European Court of Justice has since 1990 firmly established the principle of non-discrimination on the ground of sex in relation to pregnant women in the access to employment, working conditions and dismissal. Specific obligations apply to member states and employers since Directive 92/85 entered into force, which has not been amended since. The case of the Court has significantly enhanced the protection against a refusal to enrol or a dismissal linked to pregnancy. This contribution offers a short overview of the relevant EU legislation and an analysis of the case law of the Court on the protection and rights in relation to pregnancy and maternity.
\end{abstract}

KEYWORDS : Sex Discrimination, Pregnancy, Maternity, EU Law, CJEU Case Law. 
he case law of the Court of Justice of the EU (hereafter: CJEU or Court) on the prohibition of direct sex discrimination has since 1990 contributed to protect women participating in the labour market in particular when they are denied a job, have less favourable working conditions and are dismissed in relation to pregnancy and/or maternity, both in the private and public sector ${ }^{1}$. Since the implementation of the Pregnancy Directive 92/85 which aims at the introduction of measures to encourage improvements in the safety and health at work of pregnant workers and workers who have recently given birth or are breastfeeding, specific protection and rights exist in this field ${ }^{2}$. A proposal to amend this directive was published in 2008, which included among others a right to maternity leave of 18 weeks fully paid instead of the 14 weeks in the Directive 92/85 which are partially paid ${ }^{3}$. Since lengthy negotiations did not result in adopting the proposal, the European Commission decided to withdraw it ${ }^{4}$. In relation to pregnancy, birth and breastfeeding, it is therefore still the Pregnancy Directive of 1992 that prescribes the minimum standards of protection and rights required at national level. The CJEU has often received prejudicial questions of national courts concerning the interpretation of EU law in relation to pregnancy and maternity. Some case law of the Court has been codified in the Recast Directive 2006/54 - on the implementation of the principle of equal opportunities and equal treatment of men and women in matters of employment and occupation ${ }^{5}$.

1 The case law primarily concerns the interpretation of Article 119-EEC-Treaty (141 EC; 157 TFEU) on equal pay for equal work and work of equal value between male and female workers, as well as Directive 76/207 (Council Directive 76/207/EEC of 9 February 1976 on the implementation of the principle of equal treatment for men and women as regards access to employment, vocational training and promotion, and working conditions, OJ L 039, 14.2.1976, p. 40).

2 Council Directive 92/85/EEC of 19 October 1992 on the introduction of measures to encourage improvements in the safety and health at work of pregnant workers and workers who have recently given birth or are breastfeeding (tenth individual Directive within the meaning of Article 16 (1) of Directive 89/391/EEC), OJ L 348, 28.11.1992, p. 1.

$3 \operatorname{COM}(2008) 637$.

4 European Commission, Press release, Delivering for parents: Commission withdraws stalled maternity leave proposal and paves the way for a fresh approach, Brussels, July 1 2015: https:// ec.europa.eu/commission/presscorner/detail/en/IP 155287

5 Directive 2006/54/EC of the European Parliament and of the Council of 5 July 2006 on the implementation of the principle of equal opportunities and equal treatment of men and women in matters of employment and occupation (recast), OJ L 204, 26.7.2006, p. 23. 
In addition, a framework agreement of the European social partners on the reconciliation of work, private and family life has been implemented by a Directive on Parental Leave in $1996^{6}$. This directive has been replaced with the Parental Leave Directive 2010/187, which will be repealed by the Work-Life Balance Directive on work-life balance for parents and carers which was adopted in July $2019^{8}$.

The present paper offers an analysis of the case law of the Court relating to the pregnancy and maternity protection of women, as well as the specific rights of female workers at the birth of their child(ren). First the relevant legislation is discussed (I) ${ }^{9}$. The legal norms offer a minimum of protection; Member States can adopt more favourable provisions for workers. However, the interpretation of the Court has to be taken into account at the national level by the legislator, the courts, the equality bodies, the social partners and the employers (II). It is therefore useful to present these requirements, as well as their scope. The aim of this contribution is to discuss the most important minimum standards, without commenting in detail all the relevant CJEU cases $^{10}$.

\section{I - LEGISLATION}

Article 157 TFEU on the principle of equal pay for equal work and work of equal value between male and female workers can be invoked at national level not only against (an organ of the State), but also between individuals ${ }^{11}$. This Article prohibits direct sex

6 Directive 96/34/EC of 3 June 1996 on the framework agreement on parental leave concluded by UNICE, CEEP and the ETUC, OJ L 145 of 19.6.1996, p. 4.

7 Directive 2010/18/EU of 8 March 2010 implementing the revised Framework Agreement on parental leave concluded by BUSINESSEUROPE, UEAPME, CEEP and ETUC and repealing Directive 96/34/EC, OJ L 68, 18.3.2010, p. 13. See S. Burri, «La conciliation de la vie professionnelle, privée et familiale. L'approche juridique de l'Union européenne», Revue de l'OFCE, 2010, no. 114, p. 213.

8 Directive (EU) 2019/1158 of the European Parliament and of the Council of 20 June 2019 on work-life balance for parents and carers and repealing Council Directive 2010/18/EU, OJ L 188, 12.7.2019, p. 79. See for a discussion of the proposal: S. Burri, «The EU Proposal on Work-Life Balance and its Potential Impact in the Netherlands», in J. Pichrt and K. Koldinská (eds.), Labour Law and Social Protection in a Globalized World - Changing Realities in Selected Areas of Law and Policy, Alphen aan den Rijn, Kluwer Law International, 2018, p. 305.Directive (EU) 2019/1158 of the European Parliament and of the Council of 20 June 2019 on work-life balance for parents and carers and repealing Council Directive 2010/18/EUDirective (EU) 2019/1158 of the European Parliament and of the Council of 20 June 2019 on work-life balance for parents and carers and repealing Council Directive 2010/18/EU

9 This contribution does not address issues of statutory social security (Directive 79/7), nor the selfemployed (Directive 2010/41), nor services (Directive 2004/113). See for an overview, S. Burri, EU Gender equality law - update 2018, European network of legal experts in gender equality and non-discrimination, European Commission, November 2018: https://www.equalitylaw.eu/ downloads/4767-eu-gender-equality-law-update-2018-pdf-444-kb.

10 The cut-off date is February 1, 2019.

11 Since 8 April 1976: CJEU 8 April 1976, case 43/75 (Defrenne II), ECLI:EU:C:1976:56. See also Article 4 of Directive 2006/54. 
discrimination ${ }^{12}$ - for example a disadvantage linked to pregnancy or maternity leave ${ }^{13}$ - and indirect sex discrimination. This could for instance be the case if many more women than men would suffer a disadvantage due to the application of a sex-neutral provision, criterion or practice. Such measure is prohibited if not objectively justified by a legitimate aim and that the means of achieving that aim are appropriate and necessary ${ }^{14}$.

Directive 2006/54 prohibits sex discrimination in particular in the access to employment, vocational training, promotion, working conditions as well as dismissal (Article 14). The prohibition applies to direct and indirect discrimination as well as harassment related to sex and sexual harassment, concepts that are all defined in the directive (Article 2:1).

An instruction to discriminate is also prohibited (Article 2:2b). This could for example be at stake when an employer would require from a temporary work agency not to send a pregnant woman for fulfilling temporarily administrative tasks which she would be perfectly able to perform. Article 2:2c explicitly prohibits less favourable treatment of a woman related to pregnancy or maternity leave in the meaning of Directive 92/85. A woman on maternity leave has the right, at the end of this leave, to return to her job or to an equivalent post on terms and conditions which are no less favourable to her and to benefit from any improvement in working conditions to which she would have been entitled during her absence (Article 15). Protection of women in relation to pregnancy and maternity is allowed (Article 28:1).

Specific rights related to pregnancy and maternity are enshrined in Directive 92/85. This directive applies to pregnant workers and workers who have recently given birth or are breastfeeding (Article 2$)^{15}$. The directive prescribes measures to ensure the health and safety protection of these women. It is for example prohibited to expose them to certain chemical or biological dangerous agents (Articles 3-6) and night work is forbidden ${ }^{16}$ during the period of pregnancy and a certain period after child birth (Article 7). The Court considered in two cases that Article 19 of Directive 2006/54 on the burden of proof applies to a situation in which a breastfeeding worker challenges a decision on risk assessment (required by Article 4:1 of Directive 92/85) before a national court or other competent

12 See the definition of direct discrimination for example is Article 2:1a of Directive 2006/54.

13 For example if an employer reduces proportionally a Christmas bonus taking into account the periods that a mother is protected and has no right to work: CJEU 21 October 1999, C-333/97, (Lewen), ECLI:EU:C:1999:512 (para. 51).

14 See the definition of indirect discrimination for example in Article 2:1b in Directive 2006/54.

15 See on the concept of pregnant worker in particular the cases CJEU 26 February 2008, C-504/06, (Mayr), ECLI:EU:C:2008:119 and CJEU 11 November 2010, C-232/09, (Danosa), ECLI:EU:C:2010:674.

16 See for example on the interpretation of the Court on the provisions of Directive 76/207 (now repealed by Directive 2006/54) and night work: CJEU 25 July 1991, C-345/89, (Stoeckel), ECLI:EU:C:1991:324; CJEU 3 February 1995, C-13/93, (Minne), ECLI:EU:C:1994:39; CJEU 5 May 1994, C-421/92, (Habermann-Beltermann), ECLI:EU:C:1994:187; CJEU 13 March 1997, C-197/96, (Commission/France), ECLI:EU:C:1997:155; CJEU 4 December 1997, C-207/96, (Commission/ Italy), ECLI:EU:C:1997:583 and CJEU 19 September 2018, C-41/17, (González Castro), ECLI:EU:C:2018:736. 
State authority ${ }^{17}$. Women are entitled to a continuous period of 14 weeks maternity leave of which at least two weeks have to be allocated before and/or after confinement (Article $8)^{18}$. During this leave, women are entitled to the payment of and/or the entitlement to an adequate allowance, which must be an income at least at the level of the event of a break in her activities on grounds connected with her state of health (Article 11) ${ }^{19}$. Article 10 prohibits dismissal since the beginning of the pregnancy until the end of the maternity leave (as referred to in Article 8), save in exceptional cases not connected to pregnancy or maternity ${ }^{20}$. This Article has direct effect ${ }^{21}$.

The Charter of Fundamental Rights of the EU is also relevant in relation to the principles of equality, non-discrimination and equality between men and women (Articles 20, 21 and 23).

In addition, Article 33 on family and professional life stipulates:

- The family shall enjoy legal, economic and social protection;

- To reconcile family and professional life, everyone shall have the right to protection from dismissal for a reason connected with maternity and the right to paid maternity leave and to parental leave following the birth or adoption of a child.

The Court recognized that this Article reflects a fundamental social right ${ }^{22}$. This Article could play a more important role in horizontal relations (for example between employee and employer). The Court has recently explicitly accepted in the Bauer case the application of Article 31:2 of the Charter on annual leave in proceedings between private parties if it is impossible to interpret the national law in conformity with a provision of a directive ${ }^{23}$.

\section{II - CASE LAW OF THE COURT OF JUSTICE}

The Court considered already in 1996 that women on maternity leave provided for by national legislation are in a special position which requires them to be afforded special protection, but which is not comparable either with that of a man or with that of a woman actually at work ${ }^{24}$.

17 Cases CJEU 19 October 2017, C-531/15, (Otero Ramos), ECLI:EU:C:2017:789 and CJEU 19 September 2018, C-41/17, (González Castro), ECLI:EU:C:2018:736.

18 See for example CJEU 27 October 1998, C-411/96, (Boyle), ECLI :EU:C:1998:506, paras 45-54 and 55-66.

19 See for example CJEU 27 October 1998, C-411/96, (Boyle), ECLI :EU:C:1998:506, paras 28-44 and 81-87.

20 See also CJEU 30 June 1998, C-394/96 (Brown), ECLI:EU:C:1998:331.

21 CJEU 4 October 2001, C-438/99, (Jiménez Melgar), ECLI:EU:C:2001:509, paras 31-34.

22 CJEU 16 September 2010, C-149/10, (Zoi Chatzi), ECLI:EU:C:2010:534, para. 63.

23 CJEU 6 November 2018, joint cases C-569/16 and C-570/16, (Bauer), ECLI:EU:C:2018:871, paragraphs 64-92. See on the application of Article 21 of the Charter (non-discrimination) also CJEU 22 January 2019, C-193/17, (Cresco Investigation), ECLI:EU:C:2019:43 and the case law cited in this case.

24 CJEU 13 February 1996, C-342/93 (Gillespie), ECLI:EU:C:1999:46, para. 17. 


\section{A - ACCESS TO WORK}

In the famous Dekker case, the Court held that the refusal to appoint a woman because she is pregnant amounts to direct sex discrimination and that only the exceptions provided by the legislation can be invoked ${ }^{25}$. A comparison with a male candidate is not required ${ }^{26}$. In the Jiménez Melgar case, the Court considered that where non-renewal of a fixedterm contract is motivated by the worker's state of pregnancy, it constitutes direct sex discrimination ${ }^{27}$. This protection is of particular importance giving the increase of fixed-term contracts. The case law of the Court is strict as far as access to employment is concerned. This is less so in relation to pay.

\section{$B-P A Y$}

When the payment during the maternity leave falls under the concept of pay of Article 119 EEC (141 CE, 157 TFEU) and Directive 75/11728 (now repealed by Directive 2006/54), this does not require the obligation to full pay of female workers during the maternity leave ${ }^{29}$. In case of pregnancy-related illness, female workers who cannot work for this reason are in principle entitled to the same salary as other workers who are unfit to work on the ground of illness ${ }^{30}$.

However, a national legislation that provides that an employer may send home a woman who is pregnant, although not unfit for work, without paying her salary in full when he considers that he cannot provide work for her, is contrary to the Directives 76/207 and 92/95 31 .

The Court ruled that a sick-leave scheme which treats identically female workers suffering from a pregnancy-related illness and other workers suffering from an illness that is unrelated to pregnancy comes within the scope of Article $141 \mathrm{EC}$ (now Article 157 TFEU) and Directive 75/117/EEC (now Directive 2006/54) 32. $^{32}$

EU law does not require that full pay is maintained of a female worker absent from work due to pregnancy-related illness during pregnancy, as long as she is treated in the same way as a male worker who is absent by reason of any other illness. The amount of payment must not be so low as to undermine the objective of protecting pregnant workers. The

25 See the Articles 14:2 (sex as a determining factor); 28:1 (protection of women, in particular concerning pregnancy and maternity) and Article 3 (positive action) in Directive 2006/54.

26 CJEU 8 November 1990, case 177/88, (Dekker), ECLI:EU:C:1990:383, paras 15-18. See also for example CJEU 3 February 2000, C-207/98 (Mahlburg), ECLI:EU:C:2000:64 and Article 2:2c of Directive 2006/54.

27 Under certain circumstances, the non-renewal of a fixed-term contract might be a refusal of employment: CJEU 4 October 2001, C-438/99, (Jiménez Melgar), ECLI:EU:C:2001:509.

28 Council Directive 75/117/EEC of 10 February 1975 on the approximation of the laws of the Member States relating to the application of the principle of equal pay for men and women, OJ 1975, L 45/19, 19.2.1975, p. 19.

29 CJEU 13 February 1996, C-342/93, (Gillespie), ECLI:EU:C:1999:46, para. 25.

30 CJEU 19 November 1998, C-66/96, (Høj Pedersen), ECLI:EU:C:1998:549.

31 CJEU 19 November 1998, C-66/96, (Høj Pedersen), ECLI:EU:C:1998:549, paras 51-59.

32 CJEU 8 September 2005, C-191/03, (McKenna), ECLI:EU:C:2005:513. 
same applies to pay during periods of absences due to pregnancy-related illness after the end of maternity leave.

Since the entry into force of Directive 92/85, Article 11:2b provides the right to the maintenance of a right to payment and/or adequate allowance during maternity leave ${ }^{33}$. The concept of pay in that Article «like the definition in the second paragraph of Article 119 of the Treaty, encompasses the consideration paid directly or indirectly by the employer during the worker's maternity leave in respect of her employment. By contrast, the concept of allowance to which that provision also refers includes all income received by the worker during her maternity leave which is not paid to her by her employer pursuant to the employment relationship» ${ }^{34}$. This Article has direct effect ${ }^{35}$.

Two judgements published the same day concern the entitlement to pay supplements during pregnancy and maternity leave ${ }^{36}$. In Gassmayr the Court clarified that when a female worker is not able to work due to her pregnancy, she is entitled to pay equivalent to the average earnings she received during a reference period prior to the beginning of her pregnancy or maternity leave with the exception of the on-call duty allowance. The same is true for pay during maternity leave ${ }^{37}$.

The Court clarified in the case Parviainen that if the female worker was allotted another job with other tasks on account of her pregnancy such a worker is entitled to the basic salary, as well as pay components or supplementary allowances relating to her professional status. These are for example allowances relating to her seniority, her length of service and her professional qualifications ${ }^{38}$.

\section{C - WORKING CONDITIONS AND MATERNITY LEAVE}

The case law of the Court on working conditions mainly relates to the maternity leave and offers different forms of protection. A female worker does not have to inform her employer that she is pregnant, because the employer cannot take into account her pregnancy for the application of working conditions. A female worker who would like to return to work before the end of her parental leave has thus no obligation to inform her employer of her pregnancy, if she would not be able to carry out all of her duties due to certain legal prohibitions ${ }^{39}$.

33 See on the maintenance of pay in relation to a parental leave preceding maternity leave for example CJEU 13 February 2014, joint cases C-512/11 and 513/11, (TSN), ECLI:EU:C:2014:73.

34 CJEU 27 October 1998, C-411/96, (Boyle), ECLI:EU:C:1998:506, para. 31.

35 CJEU 1 July 2010, C-194/08, (Gassmayr), ECLI: EU:C:2010:386, paras 43-53.

36 See also CJEU 21 October 1999, C-333/97 (Lewen), ECLI:EU:C:1999:512.

37 CJEU 1 July 2010, C-194/08, (Gassmayr), ECLI:EU:C:2010:386, paras 54-91.

38 CJEU 1 July 2010, C-471/08, (Parviainen), ECLI:EU:C:2010:391.

39 CJEU 27 February 2003, C-320/01 (Busch), ECLI:EU:C:2003:114, paras 38-47. See also for example CJEU 20 September 2007, C-116/06 (Kiiski), ECLI:EU:C:2007:536. 
Refusing an assessment to a female employee due to an absence related to maternity leave, and as a consequence not being promoted, amounts to direct sex discrimination ${ }^{40}$. The maternity leave period was not taken into account for calculating the required period of at least six months within a year to qualify for the assessment; this unfavourable treatment was prohibited. The Court clarified in addition that the result pursued by the Directive 76/207 (now repealed by Directive 2006/54) is substantive - not formal - equality ${ }^{41}$.

If the maternity leave coincides with the period of annual leave stipulated in a collective agreement applicable to the entire workforce, the female worker must be able to take her annual leave for a period other than her maternity leave. The purpose of the entitlement to annual leave is different from that of the entitlement to maternity leave ${ }^{42}$.

Maternity leave is intended, first, to protect a woman's biological condition during and after pregnancy and, second, to protect the special relationship between a woman and her child over the period which follows pregnancy and childbirth ${ }^{43}$. An intended mother whose child is born through a surrogacy arrangement is not entitled to maternity leave, as she has never been pregnant and given birth, even if she has been breastfeeding the baby ${ }^{44}$.

\section{D - DISMISSAL}

The Court decided already in 1990 that the dismissal of a female worker due to pregnancy forms a sex discrimination ${ }^{45}$. During maternity leave, the female worker is protected against dismissal due to her absence. However, in case of absences due to illness related to pregnancy or confinement which occur after maternity leave, the general rules apply ${ }^{46}$. The Court's case law does thus not offer specific protection after the end of the maternity leave in such situation.

40 CJEU 30 April 1998, C-136/95, (Thibault), ECLI:EU:C:1998:178. See also for example CJEU 16 February 2006, C-294/04, (Sarkatzis Herrero), ECLI:EU:C:2006:109.

41 CJEU 30 April 1998, C-136/95, (Thibault), ECLI:EU:C:1998:178, para. 26.

42 CJEU 18 March 2004, C-343/01, (Merino Gómez), ECLI:EU:C:2004:160, paras 28-41.

43 CJEU 12 July 1984, 184/83, (Hoffmann), ECLI:EU:C:1984:273, para. 25. See on the rights to leave of a father which mothers are entitled to after confinement: CJEU 30 September 2010, C-104/09, (Roca Álvarez), ECLI:EU:C:2010:561 and CJEU 19 September 2013, C-5/12, (Betriu Montull), ECLI:EU:C:2013:571. See for a discussion of the approach of the Court in these cases E. Caracciolo di Torella, "Brave New Fathers for a Brave New World? Fathers and Caregivers in an evolving European Union», European Law Journal 20 (2014), p. 88; S. Burri, «Parents who want to reconcile work and care: which equality under EU law ?», in M. van den Brink, S. Burri and J. Goldschmidt (dir.), Equality and human rights: nothing but trouble? Liber amicorum Titia Loenen, Utrecht: SIM/ Universiteit Utrecht, 2015, p. 261.

44 CJEU 18 March 2014, C-167/12 (C.D.), ECLI:EU:C:2014:169 and CJEU 18 March 2014, C-363/12, (Z.), ECLI:EU:C:2014:159. See for an analysis of these cases S. Burri, «Care in Family Relations - the Case of Surrogacy Leave», European Journal of Law Reform, 17(2), 2015, p. 271; E. Caracciolo di Torella and P. Foubert, «Surrogacy, Pregnancy and Maternity Rights: A Missed Opportunity for a More Coherent Regime of Parental Rights in the EU», European Law Review, 40(10) 2015, p. 52.

45 CJEU 8 November 1990, C-179/88, (Hertz), ECLI:EU:C:1990:384.

46 CJEU 8 November 1990, C-179/88, (Hertz), ECLI:EU:C:1990:384, paras 17-19. 
Different judgements concern the protection against dismissal and protections aimed at reinforcing the position of female workers confronted with dismissals linked to pregnancy and/or maternity. Article 10 of Directive 92/85 prohibits a dismissal from the beginning of the pregnancy until the end of the maternity leave, safe in exceptional cases not connected to pregnancy.

This Article does not only prohibit the notification of a decision to dismiss linked to pregnancy and/or the birth of a child during the protected period, but also to take preparatory steps for such decision before the end of that period ${ }^{47}$. Such decision is also contrary to Directive 76/207 (now repealed by Directive 2006/54), even if the decision is notified after the end of the leave ${ }^{48}$.

The EU member states have the obligation to introduce into their national legal systems such measures as are necessary to ensure judicial protection for workers whose employer, after the employment relationship has ended, refuses to provide references as a reaction to legal proceedings brought to enforce compliance with the principle of equal treatment ${ }^{49}$.

A specific remedy concerning the prohibition of dismissal of pregnant workers or workers who have recently given birth or are breastfeeding is not contrary to EU law, provided however that those rules are no less favourable than those governing similar domestic actions. The principles of equivalence and effectiveness have to be respected ${ }^{50}$.

Directive 76/207 and Article 10 of Directive 92/85 prohibit dismissal related to pregnancy of a woman enrolled for a fixed-term who cannot work during a substantial part of the term of the contract ${ }^{51}$. The period of the employment contract has no consequence for the extent of the protection afforded by EU law to pregnant workers. This is also the case if the female worker has not informed her employer of her pregnancy.

This case law reflects the strong protection guaranteed to pregnant women against a discriminatory dismissal. Exceptions not related to pregnancy, confinement or breastfeeding are only allowed under certain conditions, for example in case of collective redundancies ${ }^{52}$.

47 CJEU 11 October 2007, C-460/06, (Paquay), ECLI:EU:C:2007:601.

48 CJEU 11 October 2007, C-460/06, (Paquay), ECLI:EU:C:2007:601, paras 34-54.

49 CJEU 22 September 1998, C-185/97), (Coote), ECLI:EU:C:1998:424. In this case, the complaint was about pregnancy discrimination.

50 CJEU 29 October 2009, C-63/08, (Pontin), ECLI:EU:C:2009:666.

51 CJEU 4 October 2001, C-109/00, (Tele Danmark), ECLI:EU:C:2001:513. See also CJEU 14 July 1994, C-32/93, (Webb), ECLI:EU:C:1994:300.

52 See in particular the case CJEU 22 February 2018, C-103/16, (Porras Guisado), ECLI:EU:C:2018:99. 


\section{RIGHTS TO PREGNANCY AND MATERNITY IN THE EU}

\section{Conclusion}

Even if the EU legislator has not been able to modernise and extend the protection and the rights of female workers in relation to pregnancy, confinement and breastfeeding, the case law of the Court offers a broad protection in particular against discrimination in relation to access to employment and dismissal. This protection covers also fixed-term contracts. Specific provisions apply, in addition to the principle of equal treatment that can play a role when existing rights could not be invoked in specific situations ${ }^{53}$. Some aspects of this case law have been codified in Directive 2006/54, but certainly not all. The rich and extensive case law of the Court - even if it were only for this reason - merits certainly to be well known.

53 See in relation to the protection against dismissal the case of a female worker undergoing IVF treatment: CJEU 26 February 2008, C-506/06, (Mayr), ECLI:EU:C:2008:119, paragraphs 44-54 and in relation to parental leave: CJEU 16 September 2010, C-149/10, (Zoi Chatzi), ECLI:EU:C:2010:534, paras 3-75.

\section{SUSANNE BURRI}

Associate professor at Utrecht School of Law, Utrecht University, The Netherlands and senior expert in gender equality of the European network of legal experts in gender equality and nondiscrimination.

Research Topics: Principle of Equality in EU, Dutch and International Law, Work-Life Balance, Precarious Work Relations, Families and Law.

\section{Publications:}

S. Burri, « Articuler vie professionnelle, familiale et privée aux Pays-Bas - quelle flexibilité pour les salariés ?», Revue de Droit Comparé du Travail et de la Sécurité Sociale, 2018 (1).

S. Burri, EU Gender Equality Law. Update 2018, Luxembourg, Publications Office of the European Union, 2018: https://publications.europa.eu/en/publication-detail/-/publication/ dd711757-033f-11e9-adde-01aa75ed71a1/language-en 